\title{
Anti-DKK1 Monoclonal Antibody BHQ880
}

National Cancer Institute

\section{Source}

National Cancer Institute. Anti-DKK1 Monoclonal Antibody BHQ880. NCI Thesaurus.

Code C80040.

A humanized monoclonal antibody directed against Wht antagonist Dickkopf-1 (DKK1) with potential anti-osteolytic activity. Anti-DKK1 monoclonal antibody BHQ880 binds to and inhibits DKK1, enhancing signaling through the Wnt pathway, which may result in osteoblast differentiation and activation within the bone matrix and the reversal of tumor-induced osteolytic disease. DKK1 is a potent Wnt signaling pathway antagonist. 